\title{
Antibiogram Typing of Biofield Treated Multidrug Resistant Strains of Staphylococcus Species
}

\author{
Mahendra Kumar Trivedi ${ }^{1}$, Alice Branton ${ }^{1}$, Dahryn Trivedi ${ }^{1}$, Gopal Nayak ${ }^{1}$, Mayank Gangwar ${ }^{2}$, \\ Snehasis Jana ${ }^{2, *}$ \\ ${ }^{1}$ Trivedi Global Inc., Henderson, USA \\ ${ }^{2}$ Trivedi Science Research Laboratory Pvt. Ltd., Bhopal, India
}

\section{Email address:}

publication@trivedisrl.com (S. Jana)

\section{To cite this article:}

Mahendra Kumar Trivedi, Alice Branton, Dahryn Trivedi, Gopal Nayak, Mayank Gangwar, Snehasis Jana. Antibiogram Typing of Biofield Treated Multidrug Resistant Strains of Staphylococcus Species. American Journal of Life Sciences. Vol. 3, No. 5, 2015 , pp. 369-374. doi: 10.11648/j.ajls.20150305.16

\begin{abstract}
Antimicrobial resistance is a global health issue in the developing countries. This study was carried out to evaluate the impact of Mr. Trivedi's biofield energy treatment on multidrug resistant (MDR) clinical lab isolates (LSs) of Staphylococcus species viz. Staphylococcus haemolyticus (LS 18), Staphylococcus epidermidis (LS 21), and Staphylococcus aureus (LS 30). Each strain was divided into the two groups i.e. control and treated. The control and treated groups were analyzed for the antimicrobial susceptibility pattern, minimum inhibitory concentration (MIC), biochemical analysis and biotype number using MicroScan Walk-Away ${ }^{\circledR}$ system. The analysis was done on day 10 after biofield treatment and compared with the control group. The sensitivity of erythromycin was improved from resistant to susceptible, while levofloxacin sensitivity was also improved from intermediate to susceptible in LS 21 isolate. The MIC results showed a decrease in the concentrations of ceftriaxone, erythromycin, imipenem, and levofloxacin antimicrobials in LS 21 as compared to the control. Linezolid and vancomycin also showed decrease in MIC as compared to the control in LS 30. Overall, 20.69\% antimicrobials showed decrease in MIC value out of the tested twenty-nine after biofield treatment in Staphylococcus species. The biochemical study showed a $25 \%$ alteration in biochemical reactions as compared to the control. A significant change was reported in biotype numbers for all the three strains of MDR Staphylococcus species after biofield treatment as compared to the respective control group. On the basis of changed biotype number (306366) after biofield treatment in LS 18, the new organism was identified as Staphylococcus simulans with respect to the control species i.e. Staphylococcus haemolyticus (302302). The control group of S. epidermidis and S. aureus showed biotype number as 303064 and 757153 respectively. After biofield treatment, LS 21 and LS 30 isolates showed altered biotype number as 307064 and 317153 respectively. Overall, results conclude that biofield treatment could be used as complementary and alternative treatment strategy against multidrug resistant strains of Staphylococcus species with improved sensitivity and reduced MIC values of antimicrobial.
\end{abstract}

Keywords: Staphylococcus haemolyticus, Staphylococcus epidermidis, Staphylococcus aureus, Biofield Energy Treatment, Multidrug-Resistant, Antibiogram, Biotyping

\section{Introduction}

Staphylococci are members of the family Staphylococcaceae. They are Gram-positive, catalasepositive and appear as isolated or in irregular grape-like clusters. The classification in this family is based on the production of coagulase [1]. The genus Staphylococcus represents a broad family of species and subspecies, which are widely distributed in nature and consists of approximately 45 species. The skin and mucosal membranes are the main habitats of the human infections. Staphylococci usually maintain the symbiotic relationship with host followed by crossing the cutaneous barrier and may reach other tissues and proliferate [2]. Staphylococcus haemolyticus (S. haemolyticus) is the second most common coagulasenegative staphylococci in the human blood, and is associated with bacteremia, skin or soft tissue infections, prosthetic join infections, or meningitis [3]. S. haemolyticus and Staphylococcus lugdunensis recently reported to have association with native valve endocarditis [4]. 
Staphylococcus epidermidis (S. epidermidis) being the most prevalent species on the skin causing different central lineassociated bloodstream infections [5]. S. epidermidis is regarded as the commensal microorganism on the human skin which is mostly associated with the nosocomial infections [6]. Staphylococcus aureus (S. aureus) is classified as the major serious human pathogen causing infections worldwide, however the other strains of Staphylococcus coagulase negative cocci have recently reported to the cause serious human infections [7]. Ten major and basic causes of death worldwide are due to the nosocomial blood infections by pathogenic clinical isolates of S. aureus [8]. S. aureus produces toxins that cause various disturbances of the immune system [9]. Increased resistance among the different pathogenic strains of Staphylococcus species against broad spectrum antibiotics is the major health problem, which limits the treatment options in front of the physicians. Alternative treatment approach to alter the sensitivity profile of antimicrobials using biofield treatment on multidrug resistant (MDR) microorganism is recently reported $[10,11]$.

Biofield is the name given to the electromagnetic field that permeates and surrounds the living organisms. It is the scientifically preferred term for the biologically produced electromagnetic and subtle energy field that provides regulatory and communication functions within the organism. In spite of several study reports of the effectiveness of the biofield healing therapies [12], there are very few well-controlled and peer-reviewed experimental studies on pathogenic microorganisms. The biofield energy can be monitored by using electromyography (EMG), electrocardiography (ECG) and electroencephalogram (EEG) [13]. Mr. Trivedi has the ability to harness the energy from environment or universe and can transmit into any living or nonliving object(s) around the Universe. The objects always receive the energy and responding into useful way via biofield energy and Mr. Trivedi's unique biofield energy treatment is also known as The Trivedi Effect ${ }^{\circledR}$. Mr. Trivedi's biofield treatment was extensively studied in different fields such as in material science [14-16], agricultural science [1719], and in biotechnology [20]. Further, the biofield treatment has considerably altered the susceptibility of antimicrobials and biotype of microbes $[10,11,21]$. By considering the significant reports on the biofield treatment, the present work was designed to evaluate the influence of biofield energy treatment on MDR strains of Staphylococcus species $(S$. haemolyticus, S. epidermidis and S. aureus) with respect to antibiogram typing, biochemical reaction pattern, followed by biotyping.

\section{Materials and Methods}

\subsection{Experimental Design and Bacterial Isolates}

MDR clinical lab isolates (LSs) of $S$. haemolyticus (LS 18), S. epidermidis (LS 21) and S. aureus (LS 30) were obtained from stored stock cultures in Microbiology Lab, Hinduja Hospital, Mumbai. Each MDR strains of
Staphylococcus species was divided into two groups i.e. control and treatment.

\subsection{Biofield Treatment Strategy}

Treatment groups of each strain, in sealed pack were handed over to Mr. Trivedi for biofield treatment under laboratory conditions. Mr. Trivedi provided the treatment through his energy transmission process to the treated groups without touching the samples. The biofield treated samples were returned in the similar sealed condition and analyzed on day 10 using the standard protocols. The following parameters like antimicrobial susceptibility, minimum inhibitory concentration (MIC), biochemical reactions, and biotype number were measured using MicroScan WalkAway $^{\circledR}$ automated system (Dade Behring Inc., USA). All antimicrobials and biochemicals were procured from Sigma Aldrich, USA.

\subsection{Evaluation of Antimicrobial Susceptibility Assay}

The tests carried out on MicroScan were miniaturized of the broth dilution susceptibility tests that have been dehydrated. Briefly, the standardized suspensions of each strain were inoculated, rehydrated, and then subjected to incubation for 16 hour at $35^{\circ} \mathrm{C}$. The detailed experimental procedures and conditions were followed as per the manufacturer's instructions. Antimicrobial susceptibility patterns of MDR strains of Staphylococcus species (LS 18, LS 21, and LS 30) were studied using MicroScan WalkAway ${ }^{\circledR}$ using (Dade Behring Inc., West Sacramento, CA, USA) using Positive Breakpoint Combo 20 (PBPC 20) panel as per the clinical and laboratory standards institute (CLSI) guidelines. The antimicrobial susceptibility pattern (S: Susceptible, I: Intermediate, R: Resistant, and BLAC: $\beta$ lactamase positive) and MIC values were determined by observing the lowest antimicrobial concentration showing growth inhibition [22].

\subsection{Biochemical Study}

Biochemical studies of each MDR strains of Staphylococcus species were determined by MicroScan Walk-Away ${ }^{\circledR}$ using PBPC 20 panel system, it interprets the microbe biochemical results with the use of a photometric or fluorogenic reader. On the basis of nature of bacilli (Gramnegative or Gram-positive), it generates computerized reports using conventional panels, which utilizes the photometric reader and provide identification results. Before commencing the experiment, the NBPC 30 panel was first incubated and read on the MicroScan Walkaway system. After completion of reading on the Walkaway system, the PBPC 20 panel was removed from system and read on the Biomic system within 1 hour. MicroScan Walk-Away instrument consist of a database associated with collective information, which was required to identify the group, genera, or species of the family. Detailed experimental procedure was followed as per manufacturer-recommended instructions. Biochemicals used in the study were arabinose, arginine, bacillosamine, bile 
esculin, $\beta$-lactamases, crystal violet, indoxyl phosphatase, inulin, acidification lactose, mannitol, mannose, micrococcus screen, sodium chloride, nitrate, novobiocin, optochin, pnitro phenyl $\beta$-D-glucuronide, p-nitro phenyl $\beta$-Dgalactopyranoside, phosphatase, pyruvate, pyrolidonyl arylamidase, raffinose, rambose, sorbitol, thymidine free growth, acidification trehalose, urea, and Voges-Proskauer [22].

\subsection{Identification by Biotype Number}

The biotype number of each MDR strains of Staphylococcus species in control and treated sample was determined followed by identification of microorganism by MicroScan Walk-Away ${ }^{\circledR}$ processed panel data report with the help of biochemical reaction data [22].

\section{Results and Discussion}

\subsection{Antimicrobial Susceptibility Study}

Antimicrobial sensitivity pattern and MIC values of control and biofield treated MDR strains of Staphylococcus species are summarized in Table 1 and 2, respectively. Altered sensitivity of tested antimicrobials were observed on day 10 after biofield treatment, and compared with respect to the control. Antimicrobial sensitivity after biofield treatment in case of S. haemolyticus (LS 18) strain showed no change in twenty-seven tested antimicrobials with respect to the control. Erythromycin sensitivity was improved i.e. resistant to susceptible, while levofloxacin sensitivity was also improved from intermediate to susceptible in biofield treated S. epidermidis (LS 21). Now, erythromycin and levofloxacin are active against biofield treated $S$. epidermidis. Most of the isolates of $S$. epidermidis had been observed for multidrug resistant against penicillin, oxacillin, gentamycin, erythromycin, and doxycycline. Resistant pattern of most of the antimicrobials in control group is well supported with literature data [23]. Rest of the tested antimicrobials did not show any alteration in antimicrobial sensitivity in LS 18, LS 21 and LS 30. MIC results showed an alteration of $20.69 \%$ among twenty-nine tested antimicrobials. The MIC value of erythromycin after biofield treatment on $S$. epidermidis showed eight-fold decrease (i.e. $>4$ to $\leq 0.5 \mu \mathrm{g} / \mathrm{mL}$ ) in concentration required to inhibit the visible growth of microorganism with respect to the control. Ceftriaxone also showed four fold decrease in MIC value after biofield treatment in LS 21 with respect to control i.e. 32 to $\leq 8$ $\mu \mathrm{g} / \mathrm{mL}$. Imipenem ( $>8$ to $\leq 4 \mu \mathrm{g} / \mathrm{mL}$ ) and levofloxacin (4 to $\leq 2 \mu \mathrm{g} / \mathrm{mL}$ ) showed two-folds decrease in MIC value in biofield treated LS 21 as compared to control. Biofield treatment in S. aureus (LS 30) also showed two-fold decrease in MIC value in case of linezolid ( $>4$ to $\leq 2 \mu \mathrm{g} / \mathrm{mL}$ ) and vancomycin (4 to $\leq 2 \mu \mathrm{g} / \mathrm{mL}$ ) as compared to respective control. Remaining antimicrobials did not show any alteration in MIC values in LS 21 and LS 30. Staphylococcus haemolyticus (LS 18) did not show any alteration with respect to antimicrobial susceptibility pattern and MIC value among tested antimicrobials (Table 2).

Table 1. Effect of biofield treatment on multidrug resistant lab isolates of Staphylococcus spp. to antimicrobial susceptibility.

\begin{tabular}{|c|c|c|c|c|c|c|c|}
\hline \multirow{2}{*}{ S. No. } & \multirow{2}{*}{ Antimicrobial } & \multicolumn{2}{|l|}{ LS 18} & \multicolumn{2}{|l|}{ LS 21} & \multicolumn{2}{|l|}{ LS 30} \\
\hline & & $\mathbf{C}$ & $\mathbf{T}$ & $\mathbf{C}$ & $\mathbf{T}$ & $\mathbf{C}$ & $\mathbf{T}$ \\
\hline 1. & Amoxicillin/k-clavulanate & $\mathrm{R}$ & $\mathrm{R}$ & $\mathrm{R}$ & $\mathrm{R}$ & $\mathrm{R}$ & $\mathrm{R}$ \\
\hline 2. & Ampicillin/sulbactam & $\mathrm{R}$ & $\mathrm{R}$ & $\mathrm{R}$ & $\mathrm{R}$ & $\mathrm{R}$ & $\mathrm{R}$ \\
\hline 3. & Ampicillin & BLAC & BLAC & BLAC & BLAC & BLAC & BLAC \\
\hline 4. & Azithromycin & $\mathrm{R}$ & $\mathrm{R}$ & $\mathrm{R}$ & $\mathrm{R}$ & $\mathrm{R}$ & $\mathrm{R}$ \\
\hline 5. & Cefazolin & $\mathrm{R}$ & $\mathrm{R}$ & $\mathrm{R}$ & $\mathrm{R}$ & $\mathrm{R}$ & $\mathrm{R}$ \\
\hline 6. & Cefepime & $\mathrm{R}$ & $\mathrm{R}$ & $\mathrm{R}$ & $\mathrm{R}$ & $\mathrm{R}$ & $\mathrm{R}$ \\
\hline 8. & Ceftriaxone & $\mathrm{R}$ & $\mathrm{R}$ & $\mathrm{R}$ & $\mathrm{R}$ & $\mathrm{R}$ & $\mathrm{R}$ \\
\hline 9. & Cephalothin & $\mathrm{R}$ & $\mathrm{R}$ & $\mathrm{R}$ & $\mathrm{R}$ & $\mathrm{R}$ & $\mathrm{R}$ \\
\hline 10. & Chloramphenicol & $\mathrm{S}$ & $\mathrm{S}$ & $\mathrm{S}$ & $\mathrm{S}$ & $\mathrm{R}$ & $\mathrm{R}$ \\
\hline 11. & Ciprofloxacin & $\mathrm{R}$ & $\mathrm{R}$ & $\mathrm{R}$ & $\mathrm{R}$ & $\mathrm{R}$ & $\mathrm{R}$ \\
\hline 12. & Clindamycin & $\mathrm{R}$ & $\mathrm{R}$ & $\mathrm{R}$ & $\mathrm{R}$ & $\mathrm{R}$ & $\mathrm{R}$ \\
\hline 13. & Erythromycin & $\mathrm{R}$ & $\mathrm{R}$ & $\mathrm{R}$ & $\mathrm{S}$ & $\mathrm{R}$ & $\mathrm{R}$ \\
\hline 14. & Gatifloxacin & I & I & $\mathrm{S}$ & $\mathrm{S}$ & $\mathrm{R}$ & $\mathrm{R}$ \\
\hline 16. & Imipenem & $\mathrm{R}$ & $\mathrm{R}$ & $\mathrm{R}$ & $\mathrm{R}$ & $\mathrm{R}$ & $\mathrm{R}$ \\
\hline 17. & Levofloxacin & $\mathrm{R}$ & $\mathrm{R}$ & I & $\mathrm{S}$ & $\mathrm{R}$ & $\mathrm{R}$ \\
\hline 18. & Linezolid & $\mathrm{S}$ & $\mathrm{S}$ & $\mathrm{S}$ & $\mathrm{S}$ & - & $\mathrm{S}$ \\
\hline 19. & Moxifloxacin & $\mathrm{S}$ & $\mathrm{S}$ & $\mathrm{S}$ & $\mathrm{S}$ & $\mathrm{R}$ & $\mathrm{R}$ \\
\hline 20. & Ofloxacin & $\mathrm{R}$ & $\mathrm{R}$ & I & I & $\mathrm{R}$ & $\mathrm{R}$ \\
\hline 21. & Oxacillin & $\mathrm{R}$ & $\mathrm{R}$ & $\mathrm{R}$ & $\mathrm{R}$ & $\mathrm{R}$ & $\mathrm{R}$ \\
\hline 22. & Penicillin & BLAC & BLAC & BLAC & BLAC & BLAC & BLAC \\
\hline 23. & Rifampin & $\mathrm{R}$ & $\mathrm{R}$ & $\mathrm{R}$ & $\mathrm{R}$ & $\mathrm{R}$ & $\mathrm{R}$ \\
\hline 24. & Synercid & $\mathrm{S}$ & $\mathrm{S}$ & $\mathrm{S}$ & $\mathrm{S}$ & $\mathrm{S}$ & $\mathrm{S}$ \\
\hline 25. & Tetracycline & $\mathrm{R}$ & $\mathrm{R}$ & $\mathrm{S}$ & $\mathrm{S}$ & $\mathrm{R}$ & $\mathrm{R}$ \\
\hline 26. & Trimethoprim/sulfamethoxazole & $\mathrm{R}$ & $\mathrm{R}$ & $\mathrm{R}$ & $\mathrm{R}$ & $\mathrm{R}$ & $\mathrm{R}$ \\
\hline 27. & Vancomycin & $\mathrm{S}$ & $\mathrm{S}$ & $\mathrm{S}$ & $\mathrm{S}$ & $\mathrm{S}$ & $\mathrm{S}$ \\
\hline
\end{tabular}

C: Control; T: Treatment; LS: Lab Isolate; R: Resistant; I: Intermediate; S: Susceptible; LS 18: S. haemolyticus; LS 21: S. epidermidis; LS 30: S. aureus; BLAC: $\beta$-lactamase positive; -: Not tested. 
Table 2. Minimum inhibitory concentration (MIC) of tested antimicrobials for multidrug resistant lab isolates of Staphylococcus spp.

\begin{tabular}{|c|c|c|c|c|c|c|c|}
\hline \multirow{2}{*}{ S. No. } & \multirow{2}{*}{ Antimicrobial } & \multicolumn{2}{|l|}{ LS 18} & \multicolumn{2}{|l|}{ LS 21} & \multicolumn{2}{|l|}{ LS 30} \\
\hline & & $\mathrm{C}$ & $\mathbf{T}$ & $\mathrm{C}$ & $\mathbf{T}$ & $\mathrm{C}$ & $\mathbf{T}$ \\
\hline 1. & Amoxicillin/k-clavulanate & $>4 / 2$ & $>4 / 2$ & $\leq 4 / 2$ & $\leq 4 / 2$ & $>4 / 2$ & $>4 / 2$ \\
\hline 2. & Ampicillin/sulbactam & $16 / 8$ & $16 / 8$ & $\leq 8 / 4$ & $\leq 8 / 4$ & $16 / 8$ & $16 / 8$ \\
\hline 3. & Ampicillin & $>8$ & $>8$ & 8 & 8 & $>8$ & $>8$ \\
\hline 4. & Azithromycin & $>4$ & $>4$ & $>4$ & $>4$ & $>4$ & $>4$ \\
\hline 5. & Cefazolin & $>16$ & $>16$ & $\leq 8$ & $\leq 8$ & $>16$ & $>16$ \\
\hline 6. & Cefepime & $>16$ & $>16$ & $\leq 8$ & $\leq 8$ & $>16$ & $>16$ \\
\hline 7. & Cefotaxime & $>32$ & $>32$ & $\leq 8$ & $\leq 8$ & $>32$ & $>32$ \\
\hline 8. & Ceftriaxone & $>32$ & $>32$ & 32 & $\leq 8$ & $>32$ & $>32$ \\
\hline 9. & Cephalothin & $>16$ & $>16$ & $\leq 8$ & $\leq 8$ & $>16$ & $>16$ \\
\hline 10. & Chloramphenicol & $\leq 8$ & $\leq 8$ & $\leq 8$ & $\leq 8$ & $>16$ & $>16$ \\
\hline 11. & Ciprofloxacin & $>2$ & $>2$ & $>2$ & $>2$ & $>2$ & $>2$ \\
\hline 12. & Clindamycin & $>2$ & $>2$ & $>2$ & $>2$ & $>2$ & $>2$ \\
\hline 13. & Erythromycin & $>4$ & $>4$ & $>4$ & $\leq 0.5$ & $>4$ & $>4$ \\
\hline 14. & Gatifloxacin & 4 & 4 & $\leq 2$ & $\leq 2$ & $>4$ & $>4$ \\
\hline 15. & Gentamicin & $>8$ & $>8$ & $>8$ & $>8$ & $>8$ & $>8$ \\
\hline 16. & Imipenem & $>8$ & $>8$ & $>8$ & $\leq 4$ & $>8$ & $>8$ \\
\hline 17. & Levofloxacin & $>4$ & $>4$ & 4 & $\leq 2$ & $>4$ & $>4$ \\
\hline 18. & Linezolid & $\leq 2$ & $\leq 2$ & $\leq 2$ & $\leq 2$ & $>4$ & $\leq 2$ \\
\hline 19. & Moxifloxacin & $\leq 2$ & $\leq 2$ & $\leq 2$ & $\leq 2$ & $>4$ & $>4$ \\
\hline 20. & Nitrofurantoin & $\leq 32$ & $\leq 32$ & $\leq 32$ & $\leq 32$ & $\leq 32$ & $\leq 32$ \\
\hline 21. & Norfloxacin & $>8$ & $>8$ & $>8$ & $>8$ & $>8$ & $>8$ \\
\hline 22. & Ofloxacin & $>4$ & $>4$ & 4 & 4 & $>4$ & $>4$ \\
\hline 23. & Oxacillin & $>2$ & $>2$ & $>2$ & $>2$ & $>2$ & $>2$ \\
\hline 24. & Penicillin & $>8$ & $>8$ & 8 & 8 & $>8$ & $>8$ \\
\hline 25. & Rifampin & $>2$ & $>2$ & $>2$ & $>2$ & $>2$ & $>2$ \\
\hline 26. & Synercid & $\leq 1$ & $\leq 1$ & $\leq 1$ & $\leq 1$ & $\leq 1$ & $\leq 1$ \\
\hline 27. & Tetracycline & $>8$ & $>8$ & $\leq 4$ & $\leq 4$ & $>8$ & $>8$ \\
\hline 28. & Trimethoprim/sulfamethoxazole & $>2 / 38$ & $>2 / 38$ & $>2 / 38$ & $>2 / 38$ & $>2 / 38$ & $>2 / 38$ \\
\hline 29. & Vancomycin & $\leq 2$ & $\leq 2$ & $\leq 2$ & $\leq 2$ & 4 & $\leq 2$ \\
\hline
\end{tabular}

MIC values are presented in $\mu \mathrm{g} / \mathrm{mL}$; C: Control; T: Treatment; LS: Lab Isolate; LS 18: S. haemolyticus; LS 21: S. epidermidis; LS 30: S. aureus.

\subsection{Identification by Biochemical and Biotype Number Study}

Biochemical study results of control and biofield treated strains of Staphylococcus species are summarized in Table 3 and Table 4 . Results showed that overall $25 \%$ change in tested biochemical reactions among three tested MDR strains of Staphylococcus species as compared to respective control. Rambose changed from (+) positive to (-) negative reaction with respect to control in S. haemolyticus (LS 18). However, biochemicals such as acidification lactose, glycosidase, urea, and Voges-Proskauer changed from (-) negative to (+) positive reaction in LS 18 as compared to control. Only one biochemical i.e. Voges-Proskauer showed (-) negative to (+) positive reaction in S. epidermidis (LS 21) as compared to control. Basic characteristics of $S$. aureus are colony pigment, free coagulase, clumping factor, protein A, heatstable nuclease, and acid production from mannitol. Crystal violet is the characteristic positive feature of $S$. aureus, but after biofield treatment in $S$. aureus (LS 30), it was changed from $(+)$ positive to $(-)$ negative reaction. Novobiocin changed from $(+)$ positive to $(-)$ negative reaction in LS 30 with respect to control. Rest of the biochemical reactions did not show any alteration after biofield treatment.

Biochemical reactions of control MDR strains of Staphylococcus species were well supported with literature data $[28,29]$. Based on the biochemical results, significant alteration in biotype number was observed in all three strains i.e. LS 18, LS 21, and LS 30 as compared to respective control. Biofield treatment in LS 18 showed an alteration in biotype number (306366) with the identification of new organism as Staphylococcus simulans on day 10 with respect to control (302302) (Table 4). Control group of $S$. epidermidis (LS 21) and S. aureus (LS 30) strains showed biotype number as 303064 and 757153 respectively. After biofield treatment LS 21 and LS 30 showed altered biotype number as 307064 and 317153 respectively (Table 4). Biofield treatment was recently used on pathogenic microbes to alter the biotype number on the basis of changed biochemical reactions $[11,21]$.

Biofield energy treatment as an alternate and complementary medicine, now included in subcategory of energy therapies by National Center for Complementary and Alternative Medicine/National Institute of Health (NCCAM/NIH) [30]. Mr. Trivedi's biofield treatment on pathogenic microbes was extensively studied and observed for alteration in the antimicrobial sensitivity pattern, biochemical reactions, and biotype number [10,11]. Biofield treatment might involve alteration at genetic level and/or enzymatic level, which could hamper the drug ligandreceptor/protein interactions. Hence, a cascade of intracellular signals may be initiated, accelerated or inhibited 
[31]. The overall study data showed that, biofield treatment on MDR strains of Staphylococcus species improved the sensitivity pattern and decrease in MIC value of $20.69 \%$ tested antimicrobial, alter biochemical reactions, and biotype number.

Table 3. Effect of biofield treatment on multidrug resistant lab isolates of Staphylococcus spp.to the vital processes occurring in living organisms.

\begin{tabular}{|c|c|c|c|c|c|c|c|c|}
\hline \multirow{2}{*}{ S. No. } & \multirow{2}{*}{ Code } & \multirow{2}{*}{ Biochemical } & \multicolumn{2}{|c|}{ LS 18} & \multicolumn{2}{|c|}{ LS 21} & \multicolumn{2}{|c|}{ LS 30} \\
\hline & & & $\mathbf{C}$ & $\mathbf{T}$ & $\mathbf{C}$ & $\mathbf{T}$ & $\mathbf{C}$ & $\mathbf{T}$ \\
\hline 1. & ARA & Arabinose & - & - & - & - & - & - \\
\hline 2. & ARG & Arginine & + & + & - & - & + & + \\
\hline 3. & BAC & Bacillosamine & + & + & + & + & + & + \\
\hline 4. & $\mathrm{BE}$ & Bile esculin & - & - & - & - & - & - \\
\hline 5. & BL & $\beta$-lactamases & + & + & + & + & + & + \\
\hline 6. & $\mathrm{CV}$ & Crystal violet & - & - & - & - & + & - \\
\hline 7. & IDX & Indoxyl phosphatase & - & - & - & - & + & + \\
\hline 8. & INU & Inulin & - & - & - & - & - & - \\
\hline 9. & LAC & Acidification lactose & - & + & + & + & - & - \\
\hline 10. & MAN & Mannitol & - & - & - & - & + & + \\
\hline 11. & MNS & Mannose & - & - & - & - & + & + \\
\hline 12. & MS & Micrococcus screen & + & + & + & + & + & + \\
\hline 13. & NACL & Sodium chloride & + & + & + & + & + & + \\
\hline 14. & NIT & Nitrate & + & + & + & + & + & + \\
\hline 15. & $\mathrm{NOV}$ & Novobiocin & - & - & - & - & + & - \\
\hline 16. & OPT & Optochin & + & + & + & + & + & + \\
\hline 17. & PGR & Glycosidase* & - & - & - & - & - & - \\
\hline 18. & PGT & Glycosidase\# & - & + & + & + & + & + \\
\hline 19. & $\mathrm{PHO}$ & Phosphatase & - & - & + & + & + & + \\
\hline 20. & PRV & Pyruvate & - & - & - & - & - & - \\
\hline 21. & PYR & Pyrolidonyl arylamidase & + & + & - & - & - & - \\
\hline 22. & RAF & Raffinose & - & - & - & - & - & - \\
\hline 23. & RBS & Rambose & + & - & - & - & - & - \\
\hline 24. & SOR & Sorbitol & - & - & - & - & - & - \\
\hline 25. & TFG & Thymidine free growth & + & + & + & + & + & + \\
\hline 26. & TRE & Acidification trehalose & + & + & - & - & + & + \\
\hline 27. & URE & Urea & - & + & + & + & - & - \\
\hline 28. & VP & Voges-Proskauer & - & + & - & + & + & + \\
\hline
\end{tabular}

C: Control; T: Treatment; LS: Lab Isolate; LS 18: S. haemolyticus; LS 21: S. epidermidis; LS 30: S. aureus; -: negative; +: positive; *PGR: p-nitro phenyl $\beta$-Dglucuronide; \#PGT: p-nitro phenyl $\beta$-D-galactopyranoside.

Table 4. Effect of biofield treatment on multidrug resistant lab isolates of Staphylococcus spp.to distinguishing feature of the genotype.

\begin{tabular}{llll}
\hline Isolate & Group & Biotype Number & Organism Identification \\
\hline \multirow{2}{*}{ LS 18 } & C & 302302 & Staphylococcus haemolyticus \\
& T & 306366 & Staphylococcus simulans \\
LS 21 & C & 303064 & Staphylococcus epidermidis \\
& T & 307064 & Staphylococcus epidermidis \\
LS 30 & C & 757153 & Staphylococcus aureus \\
& T & 317153 & Staphylococcus aureus \\
\hline
\end{tabular}

C: Control; T: Treatment; LS: Lab Isolate; LS 18: S. haemolyticus; LS 21: S. epidermidis; LS 30: S. aureus

\section{Conclusions}

Overall results suggested the impact of biofield treatment on Staphylococcus species. Antimicrobial sensitivity results in improved sensitivity pattern of erythromycin, with eightfold decrease in MIC value (i.e. $>4$ to $\leq 0.5 \mu \mathrm{g} / \mathrm{mL}$ ), while, levofloxacin was also reported with improved sensitivity pattern with improved MIC value (4 to $\leq 2 \mu \mathrm{g} / \mathrm{mL}$ ) in biofield treated S. epidermidis. Biofield treatment on Staphylococcus species showed altered effect on $25 \%$ tested biochemicals and biotype numbers. A significant change in biotype number (306366) on the basis of altered biochemical reactions as compared to control (302302). Altered biotype number results in identification of new organism as Staphylococcus simulans with respect to control species as $S$. haemolyticus in LS 18 after biofield treatment. Based on the results, Mr. Trivedi's biofield energy treatment could be applied to improve the sensitivity pattern of antimicrobials, against multidrug resistance strains of Staphylococcus species.

\section{Acknowledgements}

The authors would like to acknowledge the whole team of PD Hinduja National Hospital and MRC, Mumbai, Microbiology Lab for their support. The generous support of Trivedi Science $^{\mathrm{TM}}$, Trivedi Master Wellness ${ }^{\mathrm{TM}}$ and Trivedi Testimonials is gratefully acknowledged.

\section{References}

[1] Heilmann C, Peters G (2000) Biology and pathogenicity of Staphylococcus epidermidis. Gram-positive pathogens ASM Press, Washington, D. C.

[2] Koneman EW, Allen SD, Janda WM, Schreckenberger PC, Winn Jr (1997) Color atlas and textbook of diagnostic microbiology. (5thedn), Lippincott, Philadelphia. 
[3] Falcone M, Campanile F, Giannella M, Borbone S, Stefani S, et al. (2007) Staphylococcus haemolyticus endocarditis: Clinical and microbiologic analysis of 4 cases. Diagn Microbiol Infect Dis 57: 325-331.

[4] John JF, Harvin A (2007) History and evolution of antibiotic resistance in coagulase negative staphylococci: Susceptibility profiles of new anti-staphylococcal agents. Ther Clin Risk Manag 3: 1143-1152.

[5] Favre B, Hugonnet S, Correa S, Sax H, Rohner P, et al. (2005) Nosocomial bacteremia: clinical significance of a single blood culture positive for coagulase-negative staphylococci. Infect Control Hosp Epidemiol 26: 697-702.

[6] Vuong C, Otto M (2002) Staphylococcus epidermidis infections. Microbes Infect 4: 481-489.

[7] Rupp ME, Crossley KB, Archer GL (1997) The Staphylococci in human disease. Infections of intravascular catheters and vascular devices. New York, Churchill Livingstone.

[8] Agvald-Ohman C, Lund B, Edlund C (2004) Multiresistant coagulase-negative staphylococci disseminate frequently between intubated patients in a multidisciplinary intensive care unit. Critic Care 8: 42-47.

[9] Dinges MM, Orwin PM, Schlievert PM (2000) Exotoxins of Staphylococcus aureus. Clin Microbiol Rev 13: 16-33.

[10] Trivedi MK, Patil S, Shettigar H, Gangwar M, Jana S (2015) An effect of biofield treatment on multidrug-resistant Burkholderia cepacia: A multihost pathogen. J Trop Dis 3: 167.

[11] Trivedi MK, Patil S, Shettigar H, Gangwar M, Jana S (2015) Antimicrobial sensitivity pattern of Pseudomonas fluorescens after biofield treatment. J Infect Dis Ther 3: 222.

[12] Benor DJ (2002) Energy medicine for the internist. Med Clin North Am 86: 105-125.

[13] Movaffaghi Z, Farsi M (2009) Biofield therapies: Biophysical basis and biological regulations. Complement Ther Clin Pract 15: $35-37,31$.

[14] Dhabade VV, Tallapragada RM, Trivedi MK (2009) Effect of external energy on atomic, crystalline and powder characteristics of antimony and bismuth powders. Bull Mater Sci 32: 471-479.

[15] Trivedi MK, Patil S, Tallapragada RM (2013) Effect of biofield treatment on the physical and thermal characteristics of silicon, tin and lead powders. J Material Sci Eng 2: 125.

[16] Trivedi MK, Nayak G, Patil S, Tallapragada RM, Latiyal O (2015) Studies of the atomic and crystalline characteristics of ceramic oxide nano powders after bio field treatment. Ind Eng Manage 4: 161 .

[17] Shinde V, Sances F, Patil S, Spence A (2012) Impact of biofield treatment on growth and yield of lettuce and tomato. Aust J Basic Appl Sci 6: 100-105.
[18] Sances F, Flora E, Patil S, Spence A, Shinde V (2013) Impact of biofield treatment on ginseng and organic blueberry yield. Agrivita J Agric Sci 35: 22-29.

[19] Lenssen AW (2013) Biofield and fungicide seed treatment influences on soybean productivity, seed quality and weed community. Agricultural Journal 8: 138-143.

[20] Nayak G, Altekar N (2015) Effect of biofield treatment on plant growth and adaptation. J Environ Health Sci 1: 1-9.

[21] Trivedi MK, Patil S, Shettigar H, Bairwa K, Jana S (2015) Phenotypic and biotypic characterization of Klebsiella oxytoca: An impact of biofield treatment. J Microb Biochem Technol 7: 203-206.

[22] Fader RC, Weaver E, Fossett R, Toyras M, Vanderlaan J, et al. (2013) Multilaboratory study of the biomic automated wellreading instrument versus MicroScan WalkAway for reading MicroScan antimicrobial susceptibility and identification panels. J Clin Microbiol 51: 1548-1554.

[23] Haque N, Hossain MA, Bilkis L, Musa AK, Mahamud C, et al. (2009) Antibiotic susceptibility pattern of Staphylococcus epidermidis. Mymensingh Med J 18: 142-147.

[24] Duran N, Ozer B, Duran GG, Onlen Y, Demir C (2012) Antibiotic resistance genes and susceptibility patterns in staphylococci. Indian J Med Res 135: 389-396.

[25] Drago L, De Vecchi E, Mombelli B, Nicola L, Valli M, et al. (2001) Activity of levofloxacin and ciprofloxacin against urinary pathogens. J Antimicrob Chemother 48: 37-45.

[26] Gardete S, Tomasz A (2014) Mechanisms of vancomycin resistance in Staphylococcus aureus. J Clin Invest 124: 28362840 .

[27] Roman F, Roldan C, Trincado P, Ballesteros C, Carazo C, et al. (2013) Detection of linezolid-resistant Staphylococcus aureus with $23 \mathrm{~S}$ rRNA and novel L4 riboprotein mutations in a cystic fibrosis patient in Spain. Antimicrob Agents Chemother 57: 2428-2429.

[28] Ishii Y, Alba J, Maehara C, Murakami H, Matsumoto T, et al. (2006) Identification of biochemically atypical Staphylococcus aureus clinical isolates with three automated identification systems. J Med Microbiol 55: 387-392.

[29] Cunha Mde L, Sinzato YK, Silveira LV (2004) Comparison of methods for the identification of coagulase-negative staphylococci. Mem Inst Oswaldo Cruz 99: 855-860.

[30] Koithan M (2009) Introducing complementary and alternative therapies. J Nurse Pract 5: 18-20.

[31] Hintz KJ, Yount GL, Kadar I, Schwartz G, Hammerschlag R, et al. (2003) Bioenergy definitions and research guidelines. Altern Ther Health Med 9: A13-A30. 